\title{
Estimating runoff in ungauged catchments from rainfall, PET and the AWBM model
}

\author{
Walter Boughton $^{1 *}$ and Francis Chiew ${ }^{2}$ \\ 1. Griffith University, Brisbane, Australia,
}

2. Department of Civil \& Environmental Engineering, the University of Melbourne

Australia

*Corresponding author - Contact details

Address: $\quad 11$ Preston Place, Brookfield, Qld. 4069 Australia

Tel: $\quad+61-7-3374-4785$

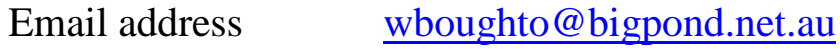

\section{Software Availability}

Program title: $\quad$ AWBM2002

Developer: $\quad$ Dr. W. Boughton

Contact address: 11 Preston Place, Brookfield, Qld. 4069, Australia

First available: $\quad 2002$

Hardware: $\quad$ PC

Source language: $\quad$ Borland Turbo Pascal 6.0

Program size: $\quad 66 \mathrm{~KB}$

Cost: $\quad$ Free

Availability: $\quad$ From developer

Program title: $\quad$ AWBMUG05

Developer: $\quad$ Dr W. Boughton

Contact address: 11 Preston Place, Brookfield, Qld. 4069, Australia

First available: $\quad 2005$

Hardware: PC

Source language: $\quad$ Borland Turbo Pascal 6.0

Program size: $\quad 60 \mathrm{~KB}$

Cost: $\quad$ Free

Availability: $\quad$ From developer

\begin{abstract}
Multiple linear regressions are used to relate average annual runoff to average annual rainfall and areal potential evapotranspiration (PET) using data from 213 catchments grouped according to location in six of the major Drainage Divisions of Australia. A method is presented for estimating daily runoff from daily rainfall data using the AWBM model, which self-calibrates its surface storage parameters to the estimate of average annual runoff from the regressions, and using default values for its baseflow parameters. Two-thirds of the estimates of average annual runoff were within $+/-25 \%$ of the actual value. The approach can also estimate satisfactorily the monthly and annual runoff series
\end{abstract}


in many catchments, with the simulations being only slightly poorer than those obtained by directly calibrating the AWBM against recorded runoff.

Keywords: AWBM; Hydrological modelling; Rainfall-runoff models; Runoff; Ungauged catchments.

\section{Introduction}

Much of the current research in catchment hydrology as well as practical management of water resources is based on computer models for estimating runoff from rainfall and evaporation data. Most of the modern rainfall-runoff models that now number in hundreds will give reliable results where some streamflow data are available for calibration of model parameters; however, very little progress has been made in use of these models on ungauged catchments where calibration data are not available.

The current situation is illustrated by two major international projects devoted to the ungauged catchment problem. The International Association of Hydrological Sciences (IAHS) established the Decade on Prediction in Ungauged Basins (PUB) program aimed at improving capability in estimating runoff from ungauged basins (http://cee.uiuc.edu/research/pub/default.asp). The international Model Parameterization Estimation Experiment (MOPEX) started in 1996 and still continuing is aimed at the estimation of parameters of rainfall-runoff models in the absence of calibration data (http://www.nws.noaa.gov/oh/mopex).

There have been a number of Australian studies directed to the estimation of runoff from ungauged catchments. The Curve Number method of the US Soil Conservation Service (Rallison 1980, Ponce and Hawkins 1996) has been tested on agricultural scale catchments (Boughton 1989) but the results were inaccurate enough that the method has not been used to any significant extent for engineering works on larger catchments. The method underestimates runoff from big events and overestimates small to medium events if calibration is made to match total estimated runoff with total recorded runoff.

In the early 1970s, the Australian Water Resources Council funded a study of runoff on small rural catchments (Snowy Mountains Engineering Corporation 1971) with the objective of calibrating a rainfall-runoff model on gauged catchments and using the results on ungauged catchments. The study by Johnston and Pilgrim (1976) showed that the modelling technology of that time was inadequate to achieve the desired objectives.

Boughton (1984) made some recommendations for use of the SFB model on ungauged catchments; however, an extensive study of the model by Nathan and McMahon (1990a,b,c) on 184 gauged catchments in south-eastern Australia did not produce any results to justify the use of the SFB on ungauged catchments. There have been other studies such as that of the MOSAZ model by Nathan et al (1996) and the IHACRES model (Croke \& Jakeman 2004) by Post and Jakeman (1999) and Post et al (1998) which have not resulted in any procedure that has attracted significant usage in engineering practice. There is a similar need elsewhere (e.g. Holmes et al 2005). 
This present study is a result of a fortuitous collation of rainfall, runoff and catchment characteristic data on 331 Australian catchments for a runoff estimation project for the National Land and Water Resources Audit (Peel et al, 2001; Chiew et al, 2002). The data have already been used in a study of the calibrations of the AWBM rainfall-runoff model for use on ungauged catchments (Boughton and Chiew, 2003). Those calibrations were made on individual catchments without any attempt to generalize the results.

In this present study, regional groupings of the rainfall, potential evapotranspiration (PET) and runoff data are used to determine linear regression equations for the estimation of average annual runoff on ungauged catchments. The estimates are used with the AWBM daily water balance model to estimate daily runoff from daily rainfall data.

The effects of six catchment characteristics on the estimates of average annual runoff were tested. The characteristics were median elevation in metres, $90^{\text {th }}$ percentile elevation minus the $10^{\text {th }}$ percentile in the catchment in metres, leaf area index, percentage of woody vegetation in the catchment, plant water holding capacity in $\mathrm{mm}$, and the lateral soil transmissivity in $\mathrm{m}^{2} /$ day.

Section 2 contains a description of the data. The linear regressions used for estimating average annual runoff from rainfall and PET, and results from testing each of the catchment characteristics, are described in Section 3. Section 4 describes the AWBM and gives an example of how it is used to estimate daily runoff values from the estimate of average annual runoff. The results of the study are summarized in Section 5. Some aspects of the method are discussed in Section 6 and some conclusions are drawn in Section 7.

\section{$2 \quad$ Data}

\section{$2.1 \quad$ Source of data}

The data set for this study comes from the rainfall, PET and runoff data prepared for a runoff estimation project for the National Land and Water Resources Audit (see Peel et al., 2001; and Chiew et al., 2002). The set originally included data from 331 unimpaired Australian catchments. "Unimpaired" is defined as data from unregulated rivers or where regulation changes the natural monthly streamflow volumes by less than five percent. The determination of whether the streamflow data is unimpaired is based on local knowledge of the respective water agencies and/or whether there is a significant dam upstream of the gauging stations, as listed in the register of dams prepared by ANCOLD - Australian National Committee on Large Dams (see Boughton, 1999).

The catchment areas range from $50 \mathrm{~km}^{2}$ to $2000 \mathrm{~km}^{2}$ and the length of streamflow data range from 10 years to 90 years. The spatial scale of $50 \mathrm{~km}^{2}$ to $2000 \mathrm{~km}^{2}$ was chosen so that the lumped daily rainfall used in the modelling has similar meaning. Where catchments are nested, the smallest sub-catchment is used, with the subsequent bigger sub-catchment used only if it is five times bigger than the smaller sub-catchment. 
The catchments are located in the more populated and important agricultural regions of Australia, in Drainage Divisions I to VI - see Figure 1. They do not represent all available data that fits the above criteria, but they generally reflect historical streamflow data availability across Australia.

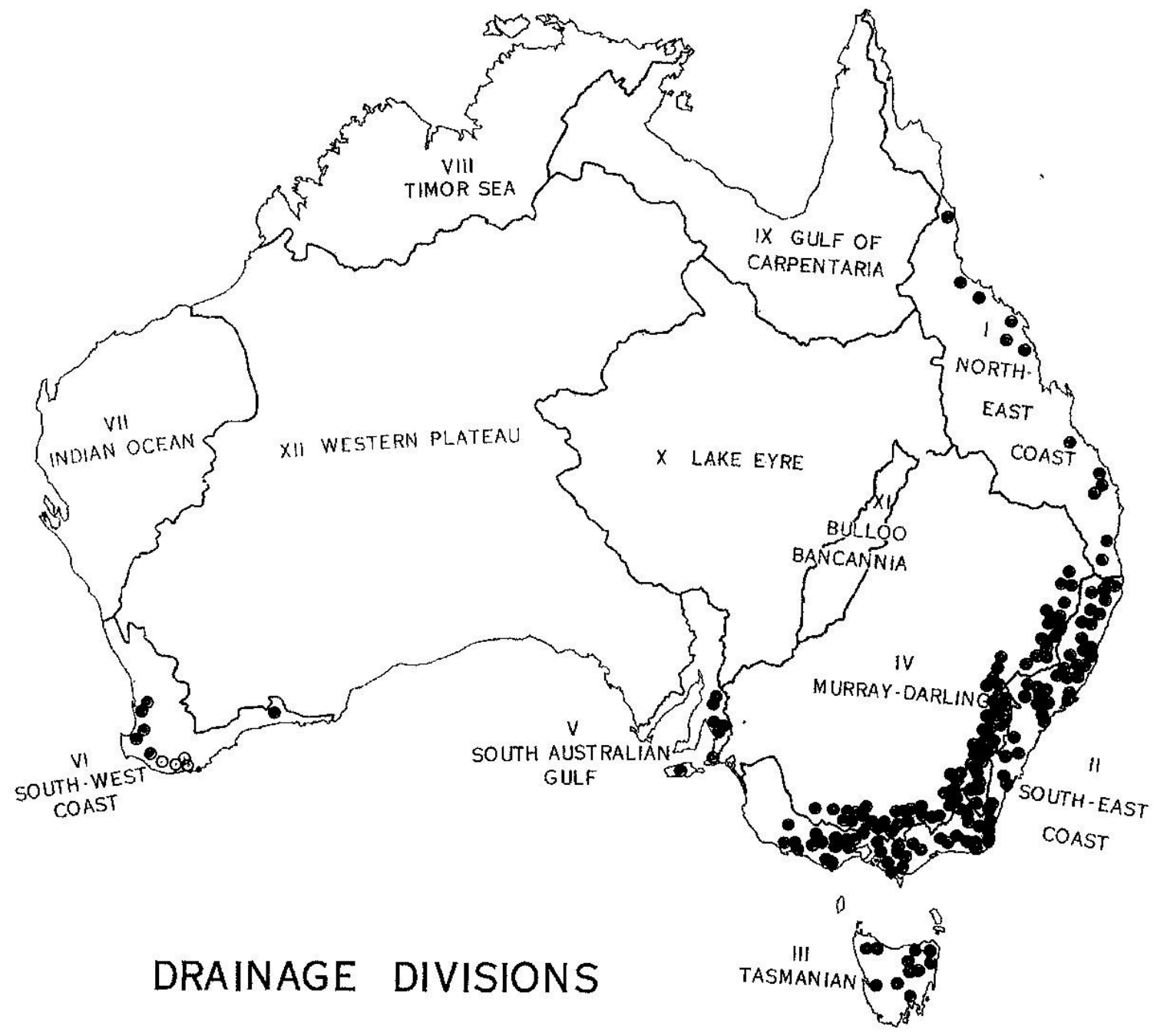

Figure 1 Drainage Divisions of Australia and locations of catchments

The source of the daily rainfall data is the Queensland Department of Natural Resources \& Mining $0.05^{\circ}$ x $0.05^{\circ}$ (about $5 \mathrm{~km} \mathrm{x} 5 \mathrm{~km}$ ) interpolated gridded rainfall data based on over 6000 rainfall stations in Australia (see www.dnr.qld.gov.au/silo). The interpolation uses Ordinary Krigging of monthly rainfall data, and a variogram with zero nugget and a variable range. The monthly rainfall for each $5 \mathrm{~km} \mathrm{x} 5 \mathrm{~km}$ point is then disaggregated to daily rainfall using the daily rainfall distribution from the station closest to the point. The lumped catchment-average daily rainfall is estimated from the daily rainfall values from each $5 \mathrm{~km} \times 5 \mathrm{~km}$ grid point within the catchment.

Compared to rainfall, evapotranspiration has little influence on the water balance at a daily time scale. The inter-annual variability of PET is also relatively small (standard 
deviation typically less than $10 \%$ of the mean). For these reasons, the mean monthly areal PET is used. The 12 mean monthly areal PET values are obtained from the evapotranspiration maps produced jointly by the Cooperative Research Centre for Catchment Hydrology and the Australian Bureau of Meteorology (Australian Bureau of Meteorology, 2001; and www.bom.gov.au/climate/averages). The areal PET values are derived using Morton's complementary relationship model (see Morton, 1983; and Chiew and McMahon, 1991).

\subsection{Selection of data}

In an earlier study (Boughton and Chiew 2003), the AWBM model was calibrated on all 331 catchments. Several different problems became apparent that resulted in discarding some of the data sets. These problems were:

- inconsistent data in which runoff exceeded rainfall for sufficient periods of time to indicate that either the rainfall or the runoff data had errors;

- data in which the rainfall showed evidence of systematic bias, i.e. that it was either too big or too small to be consistent with the runoff, resulting in calibrated parameter values that were out of physically plausible ranges;

- data with random errors between rainfall and runoff such that the resulting correlation between calculated and actual monthly runoff was sufficiently poor that there was no confidence in the calibration; and

- catchments in which there were so many periods of missing data that the period available for calibration was too short.

As a result of these problems, the data set for the Boughton and Chiew (2003) study was reduced to 221 catchments. For the present study, the number was reduced further to 213 catchments. There were only a few catchments in the Northern Territory (Divisions VIII and $\mathrm{X}$ ), which were inadequate for establishing regional relationships. In addition, two catchments with very big average annual rainfall and runoff (1 in Queensland and 1 in Tasmania) were omitted because of doubts about the accuracy of the catchment rainfall. The catchments in the present study extend from the tropics in Division I to mid-latitude temperate regions in Division III, and from east to west of the continent. Table 1 shows the number of catchments in each of the Drainage Divisions.

Table 1 Summary of catchments by Drainage Division

\begin{tabular}{|c|c|}
\hline Division & N \\
\hline I - NE Coast & 12 \\
\hline II - SE Coast & 88 \\
\hline III - Tasmania & 11 \\
\hline IV - Murray-Darling & 85 \\
\hline V - SA Gulf & 7 \\
\hline VI - SW Coast & 10 \\
\hline ALL & 213 \\
\hline
\end{tabular}


The data that were discarded because of poor quality have been used in a separate study (Boughton in press).

\subsection{Rainfall and runoff characteristics}

The data span a substantial range of average annual rainfall (390 - $2289 \mathrm{~mm} / \mathrm{yr})$ and average annual runoff ( $3-1337 \mathrm{~mm} / \mathrm{yr})$. Table 2 contains the summary statistics of average annual rainfall and runoff in the data sets.

Table 2 Rainfall and runoff in data sets

\begin{tabular}{|c|c|c|c|}
\hline Rainfall $\mathbf{~ m m} / \mathbf{y r}$ & Number & Runoff $\mathbf{~ m m} / \mathbf{y r}$ & Number \\
\hline 2289 & 1 & 1337 & 1 \\
\hline $1750-2250$ & 4 & $750-1250$ & 4 \\
\hline $1250-1750$ & 23 & $250-750$ & 59 \\
\hline $750-1250$ & 134 & $3-250$ & 149 \\
\hline $390-750$ & 51 & & \\
\hline & Total: 213 & & Total: 213 \\
\hline
\end{tabular}

\subsection{Biophysical characteristics of the catchments}

In addition to rainfall and runoff, the data included 6 characteristics of each catchment. The characteristics were evaluated as part of the National Land and Water Resources Audit (Peel et al 2001, Chiew et al 2002). These characteristics are used because they are available for all Australia.

The six characteristics are:

- Median elevation of the catchment area in metres

- Range of elevation - 90 percentile minus 10 percentile

- Leaf area index

- Percent of woody vegetation

- Plant water holding capacity - mm

- Transmissivity $-\mathrm{m}^{2} / \mathrm{day}$

The elevation characteristics are obtained from the AUSLIG 9 second Digital Elevation Model of Australia. Vegetation characteristics are derived from the Australian land cover change data sets of the Bureau of Rural Sciences (see also www.toolkit.net.au/liza). Soil characteristics are based on the estimates of soil properties by McKenzie et al (2000) for soil types classified using the Northcote (1979) classification scheme and the Atlas of Australian Soils (Northcote et al 1960-1968) (see also www.toolkit.net.au/shpa).

\section{Annual rainfall - runoff relationships}

\subsection{All data}


When average annual rainfall and runoff data from a large number of catchments are considered together, there is a spread of runoff values for any given rainfall. The larger the geographic spread of the catchments, the wider is the spread of the rainfall-runoff relationship.

Figure 2 shows average annual rainfall and runoff data for the 213 catchments used in this study. The plotted points that are at the top of the plot (more runoff for a given rainfall) are all from Tasmania.

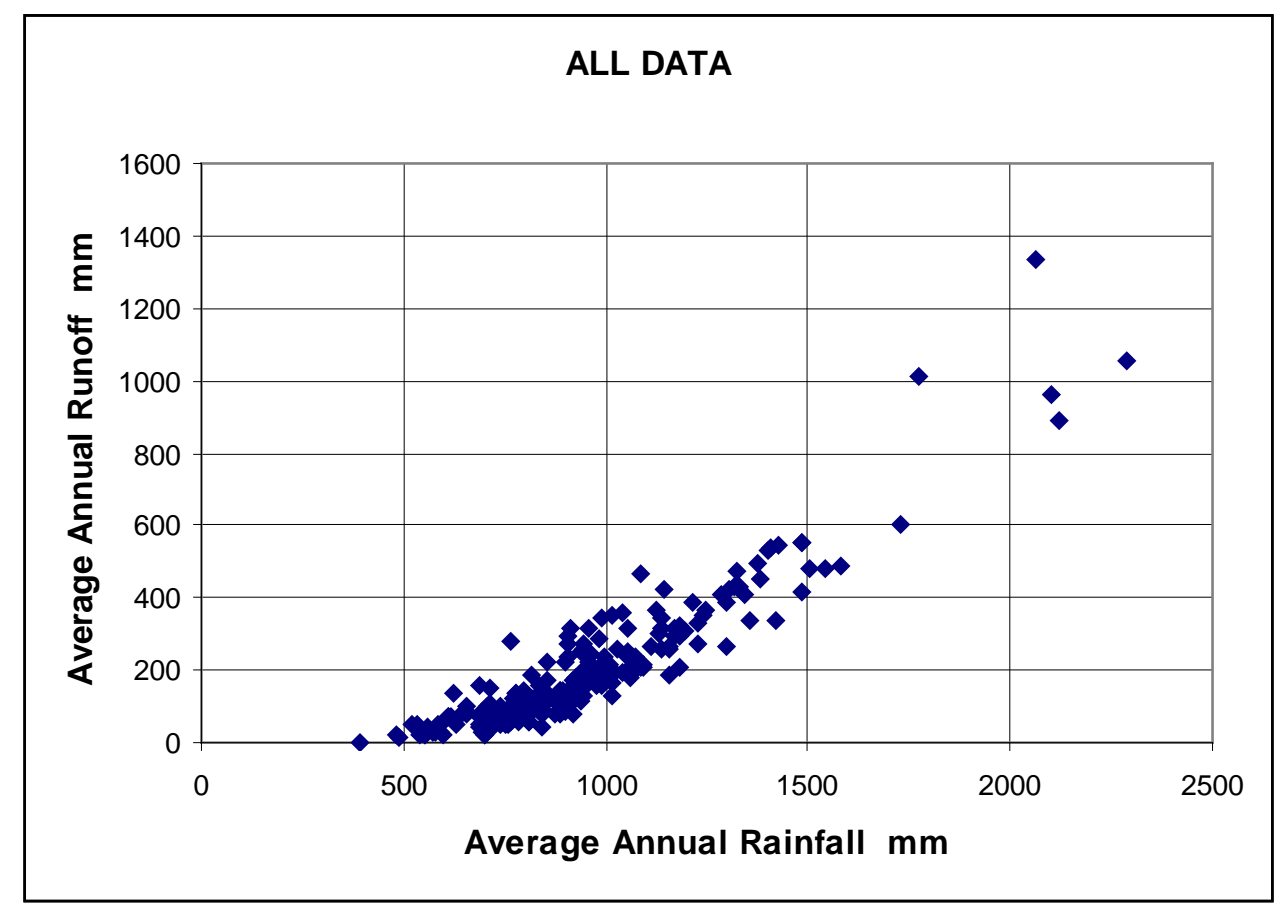

\section{Figure 2 Rainfall-runoff relationship - all data.}

\subsection{All mainland data}

When the 11 Tasmanian catchments are omitted, the remaining mainland data have a much closer rainfall-runoff relationship as shown in Figure 3. The Tasmanian data are considered later as a regional group. In the first instance, analysis was concentrated on the mainland data sets. When the Tasmanian data were removed, there were 202 data sets in the mainland group. Figure 3 shows the relationship between the average annual rainfall and average annual runoff data. 


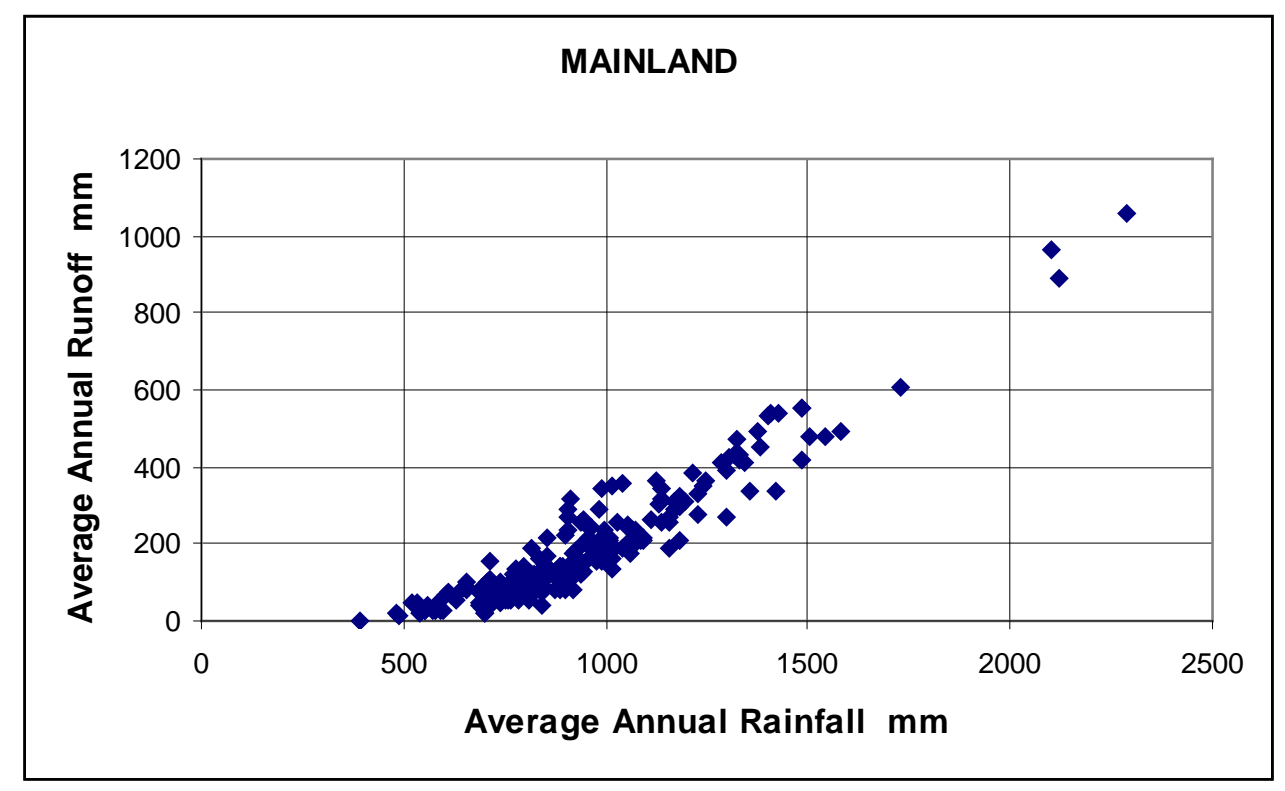

Figure 3 Rainfall-runoff relationship - mainland catchments only

The overall pattern has a typical curvilinear shape. An early attempt to fit a log-linear regression was abandoned because the extrapolation of the regression to high rainfall values produced unrealistic values of runoff. In order to make use of linear regression methods for quantitative analysis, the data were separated into three groups - those with average annual rainfall above $1000 \mathrm{~mm}$, those in the range 700 to $1000 \mathrm{~mm}$, and those less than $700 \mathrm{~mm}$.

Linear regressions were fitted to the three groups of data. The calculations were made using the LINEST function in an Excel spreadsheet. The regression equations and the coefficients of determination are as follows.

$$
\begin{array}{lll}
\text { Rain }>1000 \mathrm{~mm} / \mathrm{yr} & \mathrm{Q}=0.643 * \mathrm{P}-451 & \left(\mathrm{n}=71, \mathrm{r}^{2}=0.896\right) \\
\text { Rain } 700-1000 \mathrm{~mm} / \mathrm{yr} & \mathrm{Q}=0.561 * \mathrm{P}-343 & \left(\mathrm{n}=100, \mathrm{r}^{2}=0.499\right) \\
\text { Rain }<700 \mathrm{~mm} / \mathrm{yr} & \mathrm{Q}=0.186 * \mathrm{P}-66 & \left(\mathrm{n}=31, \mathrm{r}^{2}=0.365\right)
\end{array}
$$

Where

$$
\begin{aligned}
& \mathrm{Q}=\text { average annual runoff } \mathrm{mm} \\
& \mathrm{P}=\text { average annual rainfall } \mathrm{mm} \\
& \mathrm{n}=\text { number of catchments }
\end{aligned}
$$

The regressions do not match at the boundaries of the rainfall ranges. The top range should start at $\mathrm{P}=1317 \mathrm{~mm} / \mathrm{yr}$ for continuity, and the lowest range should finish at 739 $\mathrm{mm} / \mathrm{yr}$. When PET or other variables are added to the equations, then it is not possible to establish such exact demarcation values. The mismatches between the regressions are noted, but the problem is a minor issue in the overall problem of estimating runoff from ungauged catchments. 
There are some interesting features of the regressions. In the highest range of rainfall, each additional $\mathrm{mm}$ of rain produces $0.643 \mathrm{~mm}$ of runoff, but in the lowest range, there is only $0.186 \mathrm{~mm}$ of extra runoff, i.e. losses due to evapotranspiration, transmission loss, etc. are proportionately higher in lower rainfall areas. The coefficient of determination is highest for the highest range of rainfall and lowest for the lowest range. Other studies documented in the literature on catchment hydrology literature have also noted that relating runoff to rainfall is more difficult in lower rainfall regions than in higher rainfall areas (Hawkins 1975, Boughton and Stone 1985).

The next phase of the analysis was to see what improvement could be made by including additional variables into the regression equations. Data were available for average annual PET and for six catchment characteristics. Average annual PET and each of the catchment characteristics were added in turn to the regressions and coefficients of determination were calculated for each multiple regression. The highest coefficients occurred with average annual PET combined with rainfall in the regressions. The new set of regressions equations are as follows.

$\begin{array}{lll}\text { Rain }>1000 \mathrm{~mm} / \mathrm{yr} & \mathrm{Q}=0.659 * \mathrm{P}-0.073 * \mathrm{E}-382 & \left(\mathrm{r}^{2}=0.902\right) \\ \text { Rain } 700-1000 \mathrm{~mm} / \mathrm{yr} & \mathrm{Q}=0.571 * \mathrm{P}-0.119 * \mathrm{E}-212 & \left(\mathrm{r}^{2}=0.566\right) \\ \text { Rain }<700 \mathrm{~mm} / \mathrm{yr} & \mathrm{Q}=0.211 * \mathrm{P}-0.078 * \mathrm{E}+11 & \left(\mathrm{r}^{2}=0.550\right)\end{array}$

Where $\quad \mathrm{E}=$ average annual areal PET $\mathrm{mm}$

All of the regression coefficients for PET are negative, which is physically realistic because an increase in PET will reduce runoff. The biggest increase in the coefficient of determination is in the group of lowest rainfall, which is also physically plausible given that PET is proportionally more important in regions of small average annual runoff.

The effect of each of the catchment characteristics was then determined by adding each characteristic in turn as an additional independent variable in the multiple regression equations. Table 3 shows the coefficients of determination from the multiple linear regressions for each of the catchment characteristics added as an independent variable in turn.

Table 3 Coefficients of Determination for multiple linear regressions

\begin{tabular}{|c|c|c|c|}
\hline \multirow{2}{*}{$\begin{array}{c}\text { Independent } \\
\text { Variables }\end{array}$} & \multicolumn{3}{|c|}{ Average Annual Rainfall mm } \\
\cline { 2 - 4 } & $\mathbf{7 1 0 0 0}$ & $\mathbf{7 0 0}-\mathbf{1 0 0 0}$ & $<\mathbf{7 0 0 0}$ \\
\hline $\mathrm{P}$ & 0.896 & 0.499 & 0.365 \\
\hline $\mathrm{P}+\mathrm{E}$ & 0.902 & 0.566 & 0.550 \\
\hline $\mathrm{P}+\mathrm{E}+$ & & & \\
\hline $\mathrm{M}$ & 0.904 & 0.568 & 0.569 \\
\hline $\mathrm{R}$ & 0.903 & 0.597 & 0.552 \\
\hline $\mathrm{L}$ & 0.902 & 0.577 & 0.559 \\
\hline $\mathrm{W}$ & 0.903 & 0.578 & 0.556 \\
\hline $\mathrm{H}$ & 0.903 & 0.577 & 0.555 \\
\hline
\end{tabular}




\begin{tabular}{|l|l|l|l|}
\hline $\mathrm{T}$ & 0.903 & 0.566 & 0.553 \\
\hline
\end{tabular}

Where

$$
\begin{aligned}
& M=\text { median elevation in metres } \\
& R=\text { elevation range } 90 \%-10 \% \text { in metres } \\
& L=\text { leaf area index } \\
& W=\text { percent of woody vegetation on catchment } \\
& H=\text { plant water holding capacity } \\
& T=\text { transmissivity }
\end{aligned}
$$

Although there are some very minor improvements in isolated cells of Table 3, none of the improvements were across all rainfall ranges, and none were of significant magnitude to suggest that the characteristic had an effect that warranted including in the regression equations as a general predictor of runoff.

The effect of each catchment characteristic was then inspected visually by plotting the value of the characteristic against the residual error, i.e. calculated minus actual runoff based on equations 2.a,b,c, for each catchment. Figure 4 shows the plot for median elevation versus residual error. There is no identifiable relationship of the characteristic and the residual error. The plots for each of the other characteristics were equally devoid of any correlation.

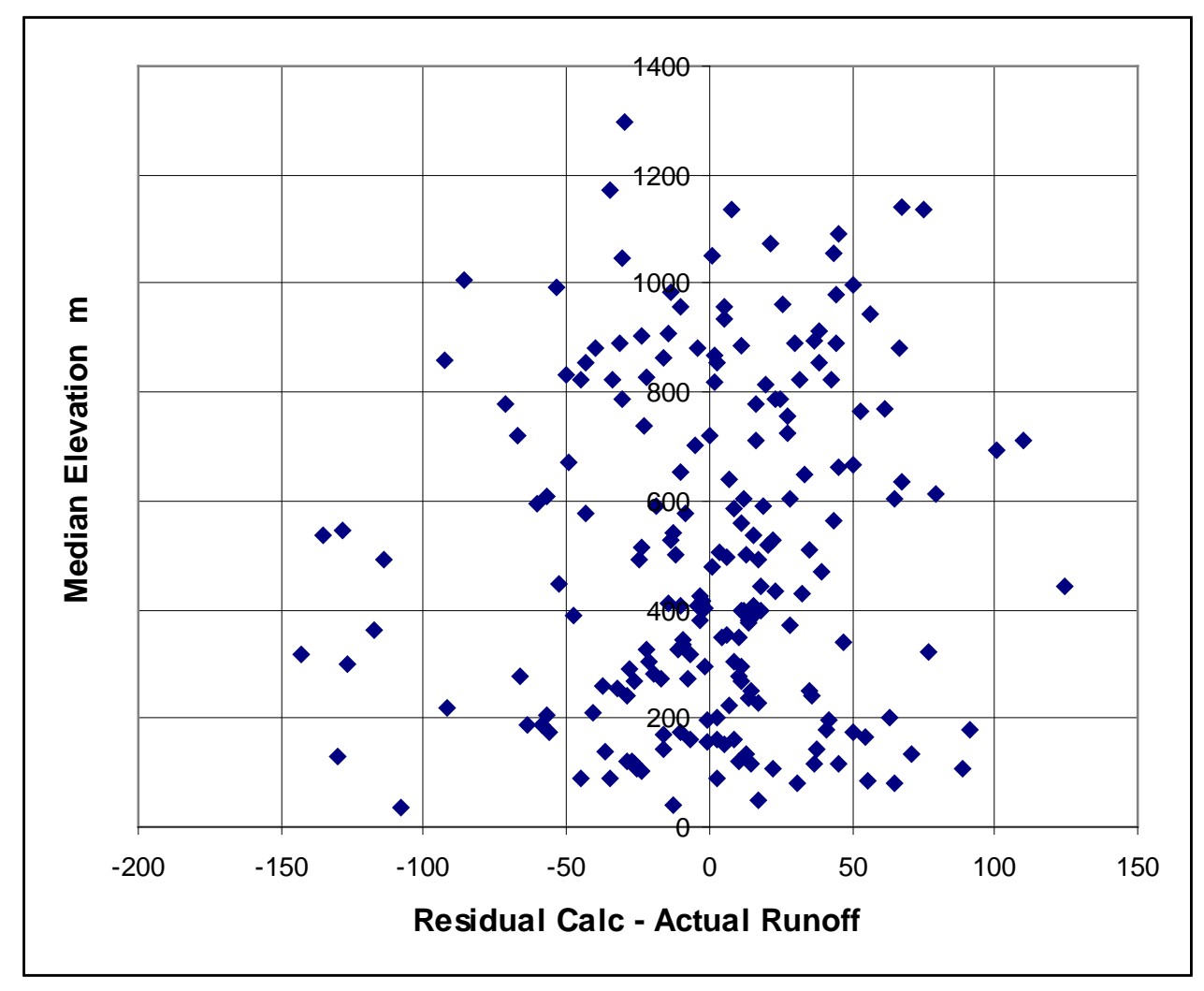

Figure 4 Median elevation of catchment plotted against residual error from regression equation. 


\subsection{Regional data sets}

The difference in the rainfall-runoff relationships between Tasmania and the mainland suggested that regional groupings of mainland data might give better relationships than that obtained from all mainland data combined. There are two major regional groups of data - 88 data sets in Drainage Division II (South-east Coast) and 85 data sets in Drainage Division IV (Murray-Darling Basin). Together, these account for some $80 \%$ of mainland data sets, and they provide an opportunity for analysis of sub-sets of data.

\section{Drainage Division II}

Of the 88 data sets in this Division, 41 have average annual rainfall $>1000 \mathrm{~mm}, 40$ are in the range $700-1000 \mathrm{~mm}$, and only 7 are in the range $<700 \mathrm{~mm}$. The 7 catchments in the lowest range of rainfall were too few to establish a reliable regression. The attempt to do so produced a negative coefficient for rainfall, i.e. more rainfall would calculate less runoff. For this reason, the lowest range was ignored and attention concentrated on the higher ranges of rainfall.

There was very small improvement over the regressions based on all mainland data. Equations 3.a,b show the Division II regressions based on rainfall alone, and equations 4.a,b show the regressions based on rainfall and PET.

$$
\begin{array}{llr}
\text { Rain }>1000 \mathrm{~mm} / \mathrm{yr} & \mathrm{Q}=0.630 * \mathrm{P}-433 & \left(\mathrm{n}=41, \mathrm{r}^{2}=0.900\right) \\
\text { Rain } 700-1000 \mathrm{~mm} / \mathrm{yr} & \mathrm{Q}=0.601 * \mathrm{P}-365 & \left(\mathrm{n}=40, \mathrm{r}^{2}=0.567\right) \\
& & \\
\text { Rain }>1000 \mathrm{~mm} / \mathrm{yr} & \mathrm{Q}=0.641 * \mathrm{P}-0.072 * \mathrm{E}-361 & \left(\mathrm{r}^{2}=0.903\right) \\
\text { Rain } 700-1000 \mathrm{~mm} / \mathrm{yr} & \mathrm{Q}=0.619 * \mathrm{P}-0.157 * \mathrm{E}-206 & \left(\mathrm{r}^{2}=0.620\right)
\end{array}
$$

(Use equation 2.c based on all mainland data for average annual rainfall $<700 \mathrm{~mm}$ )

The 88 data sets in Division II were further divided into 55 in coastal New South Wales catchments and 33 in coastal Victoria to see if the smaller regions gave better rainfallrunoff relationships. There was only very small improvement in the results - insufficient to warrant the use of the smaller regions.

The effects of adding each of the 6 catchment characteristics in turn to the regressions were tested with the Division II data in the same way as was done with all mainland data combined (Table 3). The results were again wholly negative with no significant improvement in the regressions with any of the catchment characteristics added.

\section{Drainage Division IV}

The 84 data sets in this Division were better spread among the three rainfall ranges than in Division II and there were better correlations between runoff and rainfall. There were 22 data sets with average annual rainfall $>1000 \mathrm{~mm}$, 47 in the range 700-1000 mm, and 
$15<700 \mathrm{~mm}$. The regressions based on rainfall alone are shown in equations 5.a,b,c and those with PET included in equations 6.a,b,c.

$\begin{array}{llr}\text { Rain }>1000 \mathrm{~mm} / \mathrm{yr} & \mathrm{Q}=0.630 * \mathrm{P}-710 & \left(\mathrm{n}=22, \mathrm{r}^{2}=0.931\right) \\ \text { Rain } 700-1000 \mathrm{~mm} / \mathrm{yr} & \mathrm{Q}=0.516 * \mathrm{P}-311 & \left(\mathrm{n}=47, \mathrm{r}^{2}=0.434\right) \\ \text { Rain }<700 \mathrm{~mm} / \mathrm{yr} & \mathrm{Q}=0.221 * \mathrm{P}-81 & \left(\mathrm{n}=15, \mathrm{r}^{2}=0.362\right) \\ & & \\ \text { Rain }>1000 \mathrm{~mm} / \mathrm{yr} & \mathrm{Q}=0.861 * \mathrm{P}-0.040 * \mathrm{E}-661 & \left(\mathrm{r}^{2}=0.932\right) \\ \text { Rain } 700-1000 \mathrm{~mm} / \mathrm{yr} & \mathrm{Q}=0.502 * \mathrm{P}-0.259 * \mathrm{E}+4 & \left(\mathrm{r}^{2}=0.601\right) \\ \text { Rain }<700 \mathrm{~mm} / \mathrm{yr} & \mathrm{Q}=0.276 * \mathrm{P}-0.139 * \mathrm{E}+47 & \left(\mathrm{r}^{2}=0.811\right)\end{array}$

The coefficients of determination for regressions 6.a,b,c are better than those for all mainland data together, and warrant the use of the regional groups of data for estimating average annual runoff.

\section{Other regions}

The other Divisions have much fewer data sets than Divisions II and IV - there are 12 in Division I, 11 in Division III, 8 in Division V and 10 in Division VI. Plots of average annual runoff versus average annual rainfall were prepared for each of the four Divisions. On the basis of these plots, Division VI data were divided into two subsets based on rainfall. The other Divisions used all data together to establish regression equations.

Divisions I and VI both showed positive regression coefficients for PET, i.e. an increase in PET would calculate an increase in runoff. For this reason, the regressions for these Divisions are based on rainfall only.

Table 4 gives a summary of the regression equations for estimating average annual runoff in each of Divisions I to VI, and shows the results of all mainland data together for use in regions not specifically covered by the results. The three columns at right of Table 4 show the F statistic of each regression, the degrees of freedom (df) and the probability that the $\mathrm{F}$ value could be exceeded by chance.

Table 4 Regression equations for estimating average annual runoff

\begin{tabular}{|c|c|c|c|c|c|c|c|}
\hline Region & $\begin{array}{c}\text { Rainfall } \\
\text { Range mm/yr }\end{array}$ & $\mathbf{N}$ & Regression & $\mathbf{r}^{2}$ & $\mathbf{F}$ & $\mathbf{d f}$ & Prob. \\
\hline Div I & $700-1730$ & 12 & $\mathrm{Q}=0.544 \mathrm{P}-350$ & 0.959 & 234 & 10 & $2.9 \mathrm{E}-8$ \\
\hline Div II & $>1000$ & 41 & $\mathrm{Q}=0.641 \mathrm{P}-0.0717 \mathrm{E}-361$ & 0.903 & 193 & 38 & $1.3 \mathrm{E}-20$ \\
\hline & $700-1000$ & 40 & $\mathrm{Q}=0.619 \mathrm{P}-0.157 \mathrm{E}-206$ & 0.620 & 31 & 37 & $1.1 \mathrm{E}-8$ \\
\hline & $<700$ & 7 & Use mainland & & & & \\
\hline Div III & $546-2062$ & 11 & $\mathrm{Q}=0.773 \mathrm{P}-0.902 \mathrm{E}+401$ & 0.983 & 235 & 8 & $7.8 \mathrm{E}-8$ \\
\hline Div IV & $>1000$ & 22 & $\mathrm{Q}=0.861 \mathrm{P}-0.0395 \mathrm{E}-661$ & 0.932 & 129 & 19 & $8.6 \mathrm{E}-12$ \\
\hline & $700-1000$ & 47 & $\mathrm{Q}=0.502 \mathrm{P}-0.259 \mathrm{E}+4$ & 0.601 & 33 & 44 & $6.4 \mathrm{E}-7$ \\
\hline & $<700$ & 15 & $\mathrm{Q}=0.276 \mathrm{P}-0.139 \mathrm{E}+47$ & 0.811 & 23 & 12 & $7.5 \mathrm{E}-5$ \\
\hline Div V & $490-850$ & 8 & $\mathrm{Q}=0.351 \mathrm{P}-0.171 \mathrm{E}+27$ & 0.976 & 101 & 5 & $9.1 \mathrm{E}-5$ \\
\hline Div VI & $850-1050$ & 5 & $\mathrm{Q}=0.684 \mathrm{P}-497$ & 0.673 & 6 & 3 & 0.089 \\
\hline & $390-850$ & 5 & $\mathrm{Q}=0.124 \mathrm{P}-37$ & 0.759 & 9 & 3 & 0.054 \\
\hline
\end{tabular}




\begin{tabular}{|c|c|c|c|c|c|c|c|}
\hline Mainland & $>1000$ & 71 & $\mathrm{Q}=0.659 \mathrm{P}-0.073 \mathrm{E}-382$ & 0.902 & 333 & 68 & $7.3 \mathrm{E}-36$ \\
\hline & $700-1000$ & 100 & $\mathrm{Q}=0.571 \mathrm{P}-0.119 \mathrm{E}-212$ & 0.566 & 63 & 97 & $3.1 \mathrm{E}-18$ \\
\hline & $<700$ & 31 & $\mathrm{Q}=0.211 \mathrm{P}-0.078 \mathrm{E}+11$ & 0.550 & 19 & 28 & $7.2 \mathrm{E}-6$ \\
\hline
\end{tabular}

Notes $\mathrm{N}=$ number of catchments in sample

$\mathrm{Q}=$ average annual runoff $\mathrm{mm} / \mathrm{yr}$

$\mathrm{df}=$ degrees of freedom

$\mathrm{P}=$ average annual rainfall $\mathrm{mm} / \mathrm{yr}$

Prob $=$ probability of chance result

$\mathrm{E}=$ average annual areal PET $\mathrm{mm} / \mathrm{yr}$

Table 4 gives the main results from the study for estimating average annual runoff.

\section{Estimating daily runoff values}

After estimating average annual runoff from the appropriate regression equation in Table 4, the AWBM catchment water balance model (Boughton 2004) is used to estimate daily, monthly and annual runoff from a daily rainfall record. The model calculates surface runoff and baseflow components of streamflow at daily time steps. The AWBM generates runoff by saturation excess from three surface stores that allow for partial area runoff. The surface storage parameters are the three capacities and their partial areas, and the two baseflow parameters are the baseflow index (BFI) that determines how much of the runoff is baseflow, and the baseflow recession constant $\left(\mathrm{K}_{\mathrm{b}}\right)$ that determines how fast the water is discharged from the baseflow store. The structure of the model is shown in Figure 5.

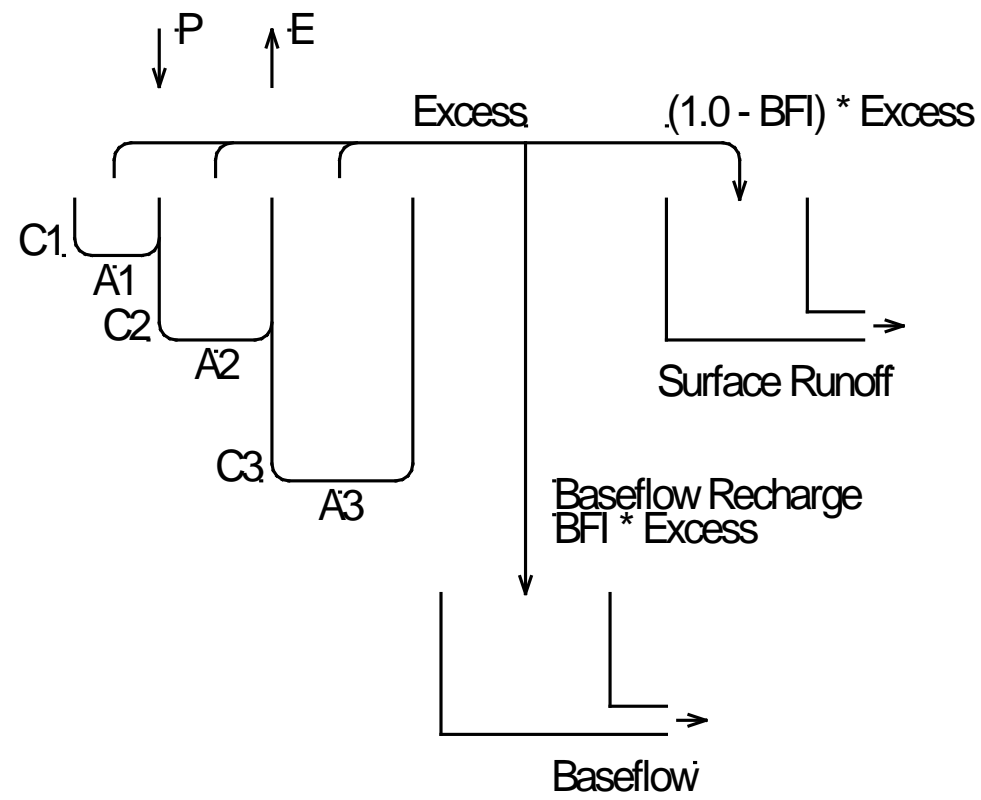

Figure 5 The AWBM model (Boughton 2004)

The AWBM2002 version of the model self-calibrates to a data set of daily rainfall, daily runoff and monthly (or average monthly) PET. This is achieved by using a fixed pattern 
of the surface storage capacities and their partial areas. A value of average surface storage capacity is determined such that the total calculated runoff matches the total actual runoff, or total estimated runoff in the case of an ungauged catchment (see Figure 6 and explanation below). When the average surface storage capacity is determined, the fixed pattern of capacities and areas are used to disaggregate the average capacity in the individual values needed to run the model. For ungauged catchments, the program AWBMUG05 uses input data of daily rainfall, monthly evaporation and an estimate of average annual runoff.

For calibration of AWBM2002 on a gauged catchment, the baseflow parameters are calibrated by trial and error adjustment to match calculated daily runoff with actual daily runoff over the period of calibration data. For use of the AWBMUG05 model on ungauged catchments, the two baseflow parameters must be estimated. Boughton and Chiew (2003) calibrated the baseflow parameters on 221 data sets including the 213 data sets used in the present study. The calibrations from that study are summarized in Table 5 for use on ungauged catchments in Australia. The values are the medians and 90\% and $10 \%$ exceedance ranges of the calibrated values in each Drainage Division.

Table 5 Values of baseflow parameters by Drainage Division

\begin{tabular}{|c|c|c|c|c|c|c|}
\hline Division & \multicolumn{3}{|c|}{ BFI } & \multicolumn{3}{c|}{ Kbase } \\
\hline & $\mathbf{9 0 \%}$ & Median & $\mathbf{1 0 \%}$ & $\mathbf{9 0 \%}$ & Median & $\mathbf{1 0 \%}$ \\
\hline I & 0.11 & 0.17 & 0.45 & 0.813 & 0.950 & 0.987 \\
\hline II & 0.21 & 0.33 & 0.60 & 0.915 & 0.980 & 0.993 \\
\hline III & 0.23 & 0.32 & 0.57 & 0.920 & 0.966 & 0.991 \\
\hline IV & 0.18 & 0.41 & 0.63 & 0.910 & 0.976 & 0.989 \\
\hline V & 0.20 & 0.29 & 0.45 & 0.950 & 0.958 & 0.985 \\
\hline VI & 0.30 & 0.56 & 0.63 & 0.900 & 0.956 & 0.981 \\
\hline
\end{tabular}

There is a surface runoff attenuation store in the top right of Figure 5. This is redundant when the model is used to estimate runoff on ungauged catchments because its effect on even daily results is very small; however, it is part of the self-calibrating version of the model (AWBM2002) that is used for producing calibrated results on each of the 213 catchments. The calibrated results are used as a base for evaluating the ungauged results in Section 5. For the ungauged calculations, the surface runoff recession constant (Ksurf) that determines the rate of discharge from the store was set at 0.35 to provide a small amount of attenuation of calculated daily surface runoff.

The procedure for calculating daily runoff is illustrated in the following steps using 23 years of data from the $108 \mathrm{~km}^{2}$ Boggy Creek catchment (station 403226) in Drainage Division IV. Average annual values of rainfall, PET and runoff for the calibration period are 1185, 1085 and $324 \mathrm{~mm} / \mathrm{yr}$ respectively.

Step 1 Estimate the average annual runoff for the location. Using the regression equation for Drainage Division IV in Table 4, the average annual runoff is estimated as:

$$
\mathrm{Q}=0.861 * \mathrm{P}-0.0395 * \mathrm{E}-661=318 \mathrm{~mm} / \mathrm{yr}
$$


which is close to the recorded value of $324 \mathrm{~mm} / \mathrm{yr}$.

Step 2 Select values for the two baseflow parameters BFI and $\mathrm{K}_{\mathrm{b}}$ using the mean values in Table 5. The mean values for Drainage Division IV are BFI $=0.41$ and $\mathrm{K}_{\mathrm{b}}=$ 0.976 , and these are selected for testing the ungauged catchment procedure. There are calibrated values for this catchment in Boughton and Chiew (2003) $\left(\mathrm{BFI}=0.60\right.$ and $\mathrm{K}_{\mathrm{b}}=$ 0.976) but these are ignored to simulate the ungauged situation.

Step 3 Select a starting value of average surface storage capacity. A value of 150 $\mathrm{mm}$ can be used in the absence of other information. Disaggregate the average value (Ave) into three partial areas and three surface storage capacities as follows:

$$
\begin{aligned}
& \mathrm{A}_{1}=0.134 \\
& \mathrm{~A}_{2}=0.433 \\
& \mathrm{~A}_{3}=0.433 \\
& \mathrm{C}_{1}=0.075 * \text { Ave } \\
& \mathrm{C}_{2}=0.762 * \text { Ave } \\
& \mathrm{C}_{3}=1.524 * \text { Ave }
\end{aligned}
$$

Run the AWBM and determine the calculated average annual runoff. If the calculated value is less than the estimate of average annual runoff, then reduce the average capacity to increase runoff. If the calculated value is more than the estimated value, then increase the average capacity to reduce runoff. This is repeated until the calculated average annual runoff is close enough to the estimate of average annual runoff for the purposes of the study. In the present study, a difference of $1 \mathrm{~mm} / \mathrm{yr}$ was used. The final stage of calibration for the Boggy Creek catchment is shown in Figure 6. An average surface storage capacity of $308 \mathrm{~mm}$ calculates an average annual runoff of $318 \mathrm{~mm}$, so the value of $308 \mathrm{~mm}$ is disaggregated as illustrated above to give the needed capacities and partial areas.

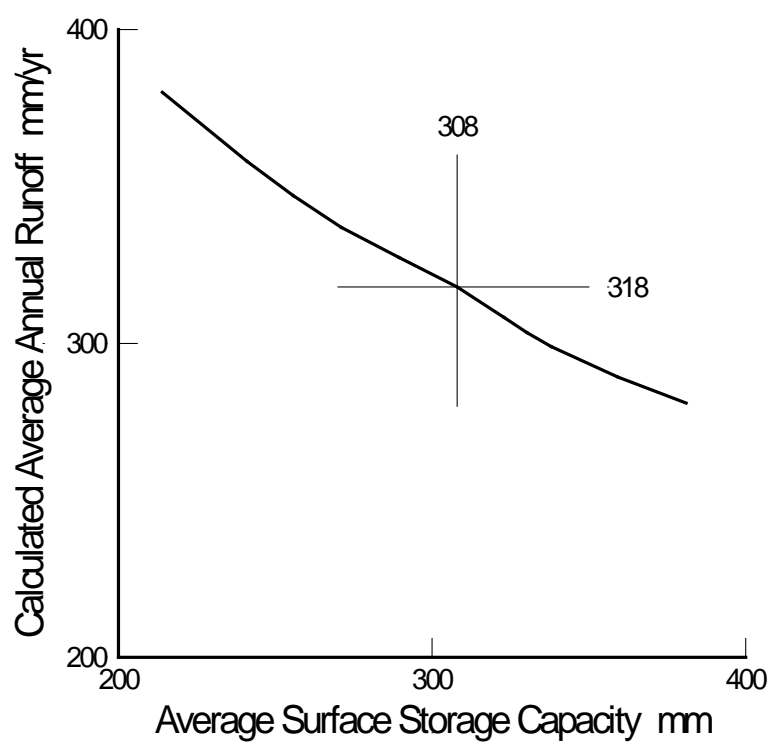


Figure 6 Determination of average surface storage capacity from estimate of average annual runoff - Boggy Creek data.

Step 4 The AWBM is run with the partial areas and capacities from Step 3 and the baseflow parameters from Step 2 to calculate daily runoff for the period of available daily rainfall record. Figure 7 shows a comparison of the estimated yearly and monthly runoff with actual values from the 23 years of streamflow record.
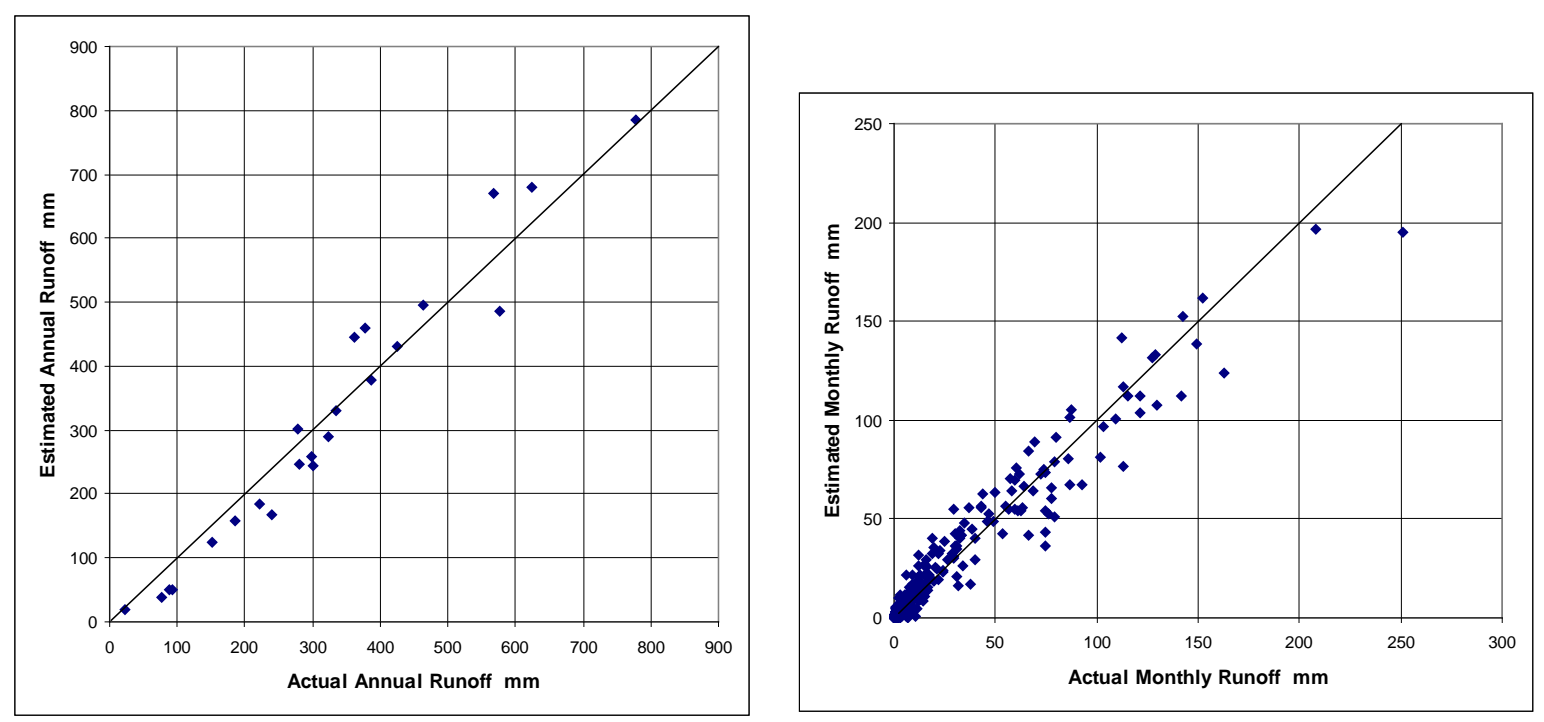

Figure 7 Comparison of estimated and actual yearly and monthly runoff on Boggy Creek catchment.

If required, a long period of stochastically generated daily rainfalls can be used in lieu of recorded daily rainfall, to estimate long term statistics of runoff from the ungauged catchment.

\section{Results}

\subsection{Average Annual Runoff}

The fitted regression equations in Table 4 were used with the rainfall and PET data to estimate average annual runoff for each of the 213 catchments. Figure 8 shows a comparison of the estimated and recorded runoff. 


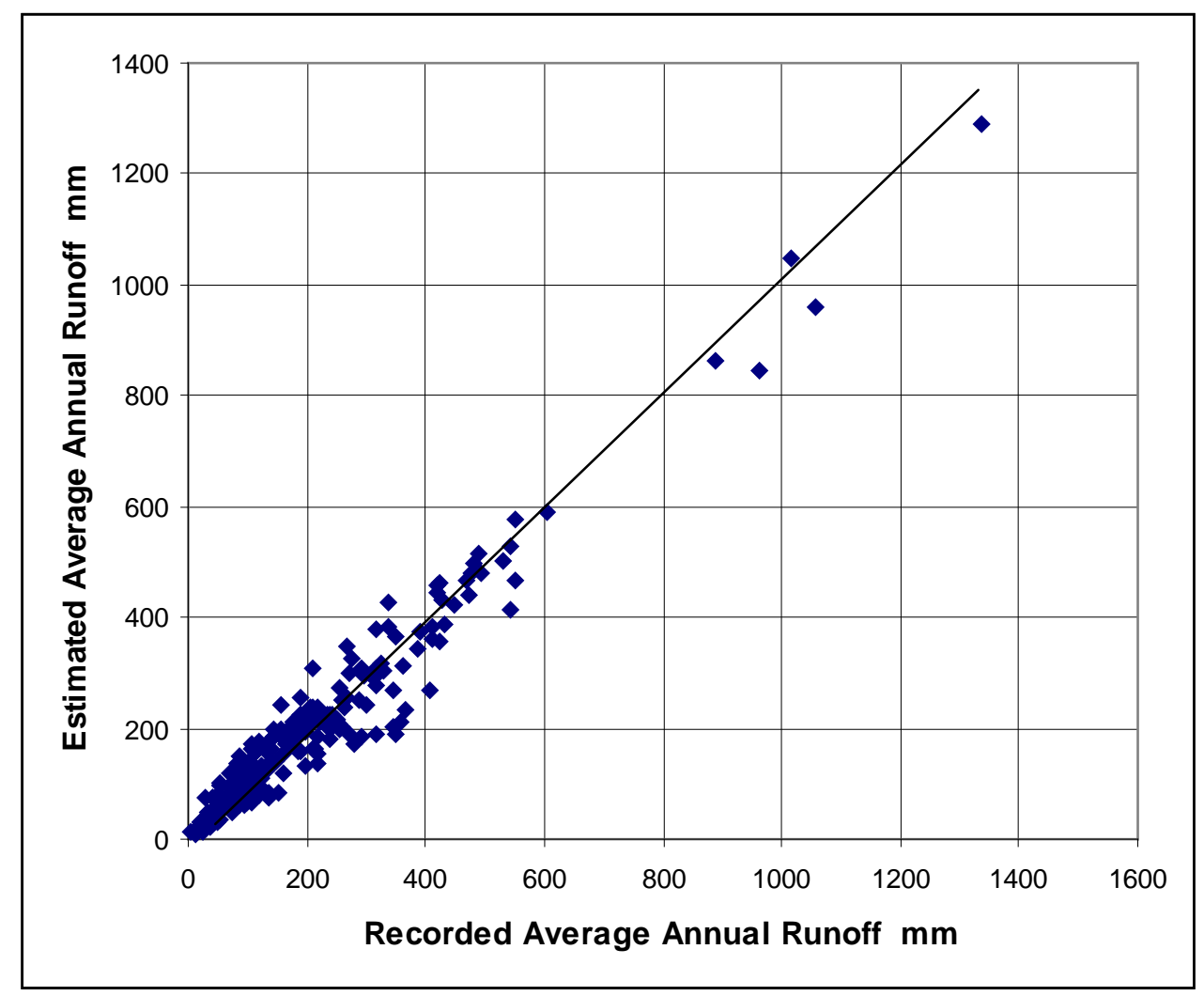

\section{Figure 8 Comparison of estimated and recorded average annual runoff}

About $40 \%$ of the estimated values were within $+/-10 \%$ of the recorded values, and about two-thirds were within $+/-25 \%$. Less than $10 \%$ of the estimated values were in error by more than $50 \%$. Figure 8 shows that the biggest percentage errors are in the lower range of runoff.

The accuracy of the estimate of average annual runoff is the main determinant of the accuracy of the monthly and yearly results, so these are acceptable results for the large area of Australia covered by the data.

\subsection{Monthly and annual runoff}

The self-calibrating version (AWBM2002) was used to calibrate the AWBM to rainfall and runoff data from each of the 213 catchments. The calculated monthly and annual totals of runoff were compared with recorded runoff by calculating coefficients of efficiency E.

$$
E=\frac{\sum_{i=1}^{n}\left(R E C_{i}-\overline{R E C}\right)^{2}-\sum_{i=1}^{n}\left(E S T_{i}-R_{E C}\right)^{2}}{\sum_{i=1}^{n}\left(R^{2} C_{i}-\overline{R E C}\right)^{2}}
$$


where ESTi is runoff estimated by the model

RECi is the recorded runoff

$\overline{\mathrm{REC}}$ is the mean recorded runoff

$\mathrm{n}$ is the number of months (or years) in the simulation.

The coefficient of efficiency expresses the proportion of variance of the recorded runoff that can be accounted for by the model (Nash and Sutcliffe, 1970) and provides a direct measure of the ability of the model to reproduce the recorded flows with $\mathrm{E}=1.0$ indicating that all the estimated flows are the same as the recorded flows.

These coefficients from the AWBM calibrations varied from about 0.3 to 0.97 depending on the quality of the input data. These coefficients based on calibrations to recorded runoff provide a base for comparison of the quality of results from the ungauged calculations.

The estimates of average annual runoff in 5.1 above, together with the mean values of the baseflow parameters in Table 5, were used with the AWBM to calculated daily runoff for the period of available daily rainfall data on each catchment. The calculated values were summed to monthly and annual totals that were compared with the corresponding recorded values. Coefficients of efficiency were calculated for both monthly and annual values. Figure 9 compares the coefficients from the ungauged calculations with the corresponding coefficients from the calibrations.

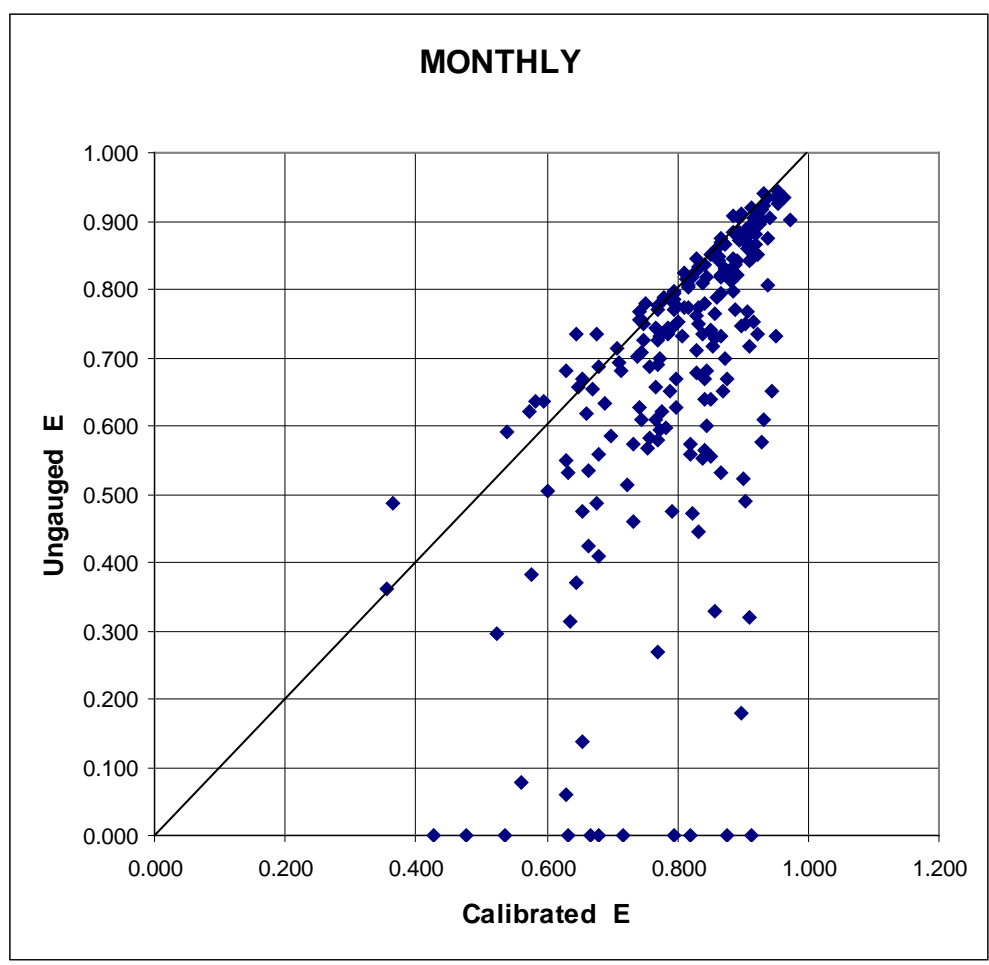

Figure 9 Coefficients of efficiency based on monthly data 
Figure 10 shows the corresponding results for the annual totals of runoff.

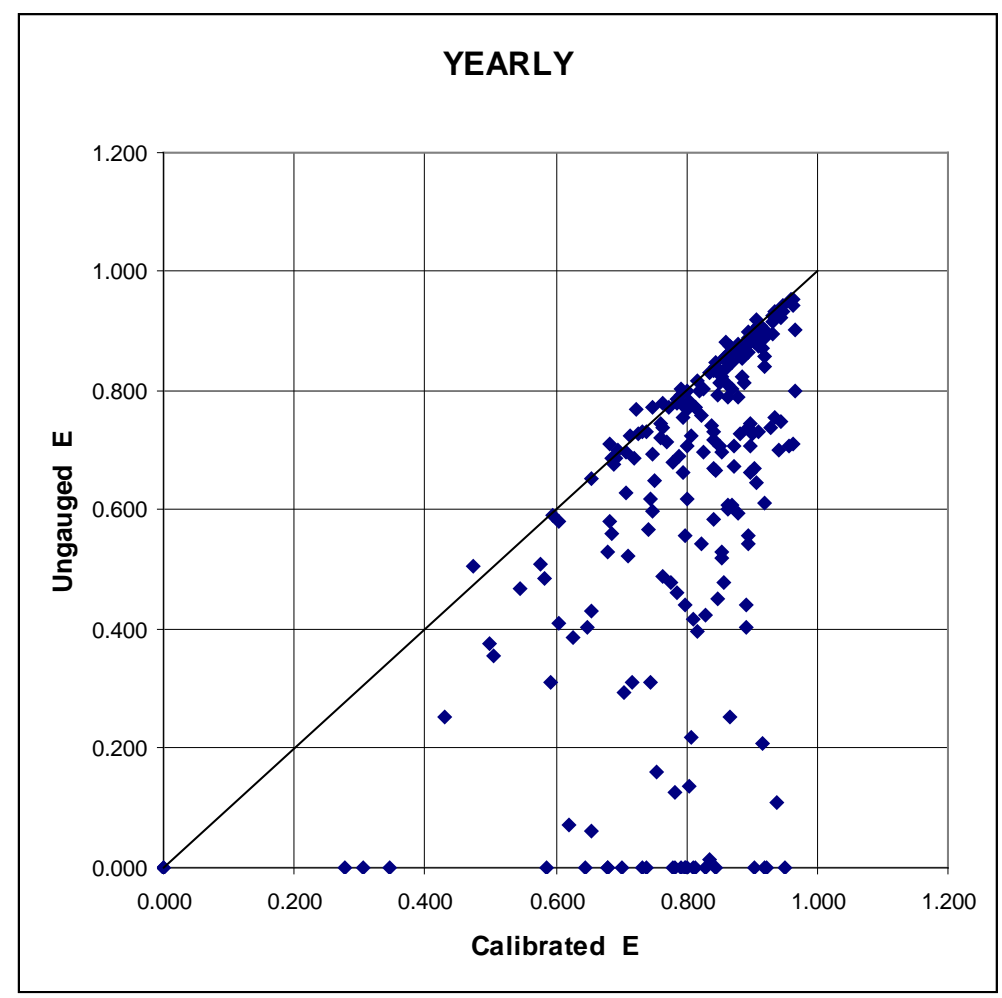

Figure 10 Coefficients of efficiency based on annual data

The differences in the coefficients of efficiency from the calibrated and ungauged calculations show the two effects of quality of input data and quality of the estimate of average annual runoff on the final results. The horizontal spread of values shows that the quality of the rainfall and PET data make the coefficient of efficiency vary from about 0.3 to 0.97 even when the model is calibrated to recorded runoff data. If all estimates of average annual runoff were perfect then the plotted points in Figures 9 and 10 would fall on a 1:1 correspondence across the middle of each plot. The vertical spread of points below each 1:1 correspondence reflects the errors in the estimates of average annual runoff. The larger the error in estimating average annual runoff, then the lower is the value of the coefficient of efficiency. Some values of $\mathrm{E}$ were negative, and such values are shown as zero for ease of plotting.

The coefficient of efficiency is particularly sensitive to error in the estimate of runoff, which is good for evaluating model calibrations, but the sensitivity is too much for the lesser quality results from ungauged catchments. The X-Y plot in Figure 8 is better for assessing the range of error in estimating runoff on ungauged catchments.

To give perspective to the Boggy Creek results shown in Figure 7, the monthly coefficients of efficiency for calibrated and ungauged calculations were 0.928 and 0.918 respectively, and the corresponding yearly values were 0.911 and 0.908 . These values are 
in the dense cluster in the top right of both Figures 9 and 10, and are typical of the better results that were obtained from many of the catchments. They are neither the best among the data sets nor of unusually good quality. The overall results indicate that the method based on the AWBM can be used to estimate runoff with good results on many catchments. However, the simulations can be poor in some catchments.

An interesting feature of both Figures 9 and 10 is that a few coefficients of efficiency from the ungauged estimates are slightly higher than the corresponding calibrated coefficients. The explanation of this is that the automatic calibration of the AWBM does not maximize the coefficient of efficiency. The surface storage parameters that determine the total amount of runoff are calibrated to make total calculated runoff equal to total recorded runoff. In some data sets, there are particular months and years with large differences between calculated and recorded runoff (outliers) that have a big effect on the coefficient of efficiency. In a few cases, change in the value of total runoff used for calibration can produce a slight increase in the coefficient. Figures 9 and 10 show that the improvements are few in number and small in magnitude, but the results needs some explanation.

\section{Discussion}

\subsection{Sources of error}

The method is based on the ability of the AWBM model to calibrate its surface storage parameters to an estimate of average annual runoff, combined with estimates of baseflow parameters. Because the AWBM reproduces the estimated average annual runoff in its calculations, the regression based estimate of average annual runoff is the main factor determining the quality of the results. The quality of the input data is the other main determinant of the quality of the results. For ungauged catchments, the quality of the data mainly depends on the selection of rainfall data to represent the runoff generating rainfall over the catchment area of interest.

The estimates of monthly and annual runoff are not much affected by the assumed values of the baseflow parameters in the AWBM, but these parameters have a much greater effect on the calculated daily values of runoff. While several studies have attempted to provide relationships for estimation of BFI and $\mathrm{K}_{\mathrm{b}}$ on ungauged catchments, there is no procedure with demonstrated reliability available at the present time. It must be emphasized that estimates of daily runoff are of variable quality even when runoff data are available for calibration of a rainfall-runoff model. It is optimistic to expect good quality daily results from ungauged catchments

\subsection{Additional data}

There were 2831 flow measuring stations in operation in Australia at 31 December 1983. While some rationalization of the network since then has reduced the total number, there are still more than ten times the number of stations used in this study. This provides an opportunity for substantial improvement to the estimates of average annual runoff that are 
summarized in the regressions in Table 4. The present study, although substantial with its base of 213 catchment data sets, can be viewed as a demonstration of procedure with major opportunity for improvement on Australian catchments by use of more of the available data.

\subsection{Other estimates of average annual runoff}

A map of average annual runoff over the whole of Australia was produced by the Commonwealth Division of National Mapping in 1967 and presented as "Surface Water Resources" in the Atlas of Australian Resources. A copy was reproduced in the Review of Australia's Water Resources 1975 (Australia, Department of National Resources 1975). The scale of this map is too large for use on particular catchments, but it shows where the isolines of average annual runoff are steep, with runoff changing over small distances, or flat, with similar average annual runoff over larger areas.

There are relationships among average annual values of rainfall, runoff and PET in the climatological and geographical literature. Some of these are based on using records of runoff and rainfall to estimate PET from different vegetation covers of catchments. It is not immediately obvious what use can be made of this work, particularly as the tests of catchment characteristics on runoff in the present study gave negative results. However, there appears to be some potential for making use of the prior work on average annual runoff by others outside of the engineering discipline.

\subsection{Effects of catchment characteristics on runoff}

Six catchment characteristics were tested in turn with the regression equations but none produced any improvement to the estimates of average annual runoff. The six included two topographic characteristics, two soil characteristics and two of vegetation cover. The lack of any significant correlation with runoff is anomalous. Many other studies reported in the literature show such correlations; e.g. the difference in runoff from forested and grassed catchments is extensively reported, so the lack of any effect from the percent of woody vegetation is a significant anomaly. The characteristics were estimated from satellite observations and from broad scale soil mappings, not from field measurements, so there is a possible explanation in the methods used to estimate the characteristics.

\section{Conclusions}

The procedure outlined in the paper can be used to estimate daily runoff on ungauged catchments over much of Australia where a daily rainfall record is available. The quality of the monthly and annual results depends on the estimate of average annual runoff that is based on average annual rainfall (from the rainfall record) and average annual areal PET (from maps covering all of Australia). Two-thirds of the estimates based on the regression equations were within $+/-25 \%$ of the actual value. The regression equations have potential for improvement by the use of more of the nation's available streamflow data. 
The method based on the AWBM model can be used where estimates of average annual runoff and the two baseflow parameters are available. This ability of the AWBM to use a daily rainfall record and an estimate of average annual runoff opens new opportunities for dealing with the ungauged catchment problem.

Estimates of daily runoff are sensitive to the estimates of the baseflow parameters (BFI \& $\mathrm{K}_{\mathrm{b}}$ ) that are used in the AWBM model. The calibrated values of these parameters from an earlier study (Boughton and Chiew 2003) are the best source of information in the regions covered by the data sets, but no general relationships were established for use in other areas. The method described in this paper offers good potential for estimating monthly runoff in many areas, but the estimation of daily runoff values on ungauged catchments is dependent on the quality of the estimates of the baseflow parameters.

There will be a continuation of this work with the Australian data, but the more important need is to have the method tested by others in other regions. The AWBM software is freely available without charge by request to the senior author (email: wboughto@bigpond.net.au) It is hoped that the opportunity provided by the method will attract some to undertake tests in other areas.

\section{References}

Australian Bureau of Meteorology, 2001. Climate Atlas of Australia Evapotranspiration, Bureau of Meteorology, Australia.

Australia, Department of National Resources, 1975. Review of Australia's water resources. Aust. Gov. Publ. Serv., Canberra.

Boughton, W. C., 1984. A simple model for estimating the water yield of ungauged catchments. Civil Engg. Trans., Institution of Engineers, Australia, CE26(2), 83-88.

Boughton, W. C., 1989. A review of the USDA SCS curve number method. Australian Jour. of Soil Research, 27, 511-523.

Boughton, W.C., 1999. A Century of Water Resources Development in Australia 19001999, Institution of Engineers, Australia, 256 pp.

Boughton, W.C. 2004. The Australian water balance model. Environmental Modelling and Software, 19: 943-956.

Boughton, W. C., in press. Calibrations of a daily rainfall-runoff model with poor quality data. Accepted for publication, Environmental Modelling \& Software.

Boughton, W. and Chiew, F., 2003. Calibrations of the AWBM for use on ungauged catchments, Technical Report 03/15, CRC for Catchment Hydrology, Monash University, 37 pp. 
Boughton, W. C. and Stone, J. J., 1985. Variation of runoff with watershed area in a semi-arid location. Jour. Arid Envir. 9, 13-25.

Chiew, F.H.S., Peel, M.C. and Western, A.W., 2002. Application and testing of the simple rainfall-runoff model SIMHYD, In: Mathematical Models of Small Watershed Hydrology and Applications (Editors: V.P. Singh and D.K Frevert), Water Resources Publication, Littleton, Colorado, (ISBN 1-887201-35-1), pp. 335-367.

Chiew, F.H.S. and McMahon, T.A., 1991. The applicability of Morton's and Penman's evapotranspiration estimates in rainfall-runoff modelling, Water Resources Bulletin, 27: 611-620, 1991.

Croke, B. F. and Jakeman, A. J, 2004. A catchment moisture deficit module for the IHACRES rainfall-runoff model. Environmental Modelling \& Software, 19(1): 1-5.

Hawkins, R. H., 1975. The importance of accurate curve numbers in the estimation of storm runoff. Water Resources. Bull. 11, 887-891.

Holmes, M. G., Young, A. R., Goodwin, T. H. and Grew, R., 2005. A catchment based water resource decision-support tool for the United Kingdom. Environmental Modelling \& Software, 20(2): 197-202.

Johnston, P. R. and Pilgrim, D. H., 1976. Parameter optimization for watershed models. Water Resources Research, 12(3), 477-486.

Mckenzie, N. J., Jacquier, D. W., Ashton, L. J. and Cresswell, H. P., 2000. Estimation of soil properties using the Atlas of Australian Soils. CSIRO Land and Water, Canberra, Technical Report 11/00.

Morton, F.I., 1983. Operational estimates of actual evapotranspiration and their significance to the science and practice of hydrology, Journal of Hydrology, 66: 1-76, 1983.

Nash, J.E. and Sutcliffe, J.V., 1970. River forecasting using conceptual models, 1. a discussion of principles. Jour. Hydrology, 10: 282-290.

Nathan, R. J., Austin, K., Crawford, D. and Jayasuriya, N., 1996. The estimation of monthly yield in ungauged catchments using a lumped conceptual model. Aust. Jour. of Water Resources, 1(2), 65-75.

Nathan, R. J. and McMahon, T. A., 1990a. The SFB model part I - validation of fixed model parameters. Civil Engg. Trans., Institution of Engineers, Australia, CE32(3), 157161. 
Nathan, R. J. and McMahon, T. A., 1990b. The SFB model part II - operational considerations. Civil Engg. Trans., Institution of Engineers, Australia, CE32(3), 162-166.

Nathan, R. J. and McMahon, T. A., 1990c. The estimation of low flow characteristics and yield from small ungauged rural catchments. AWRAC Research Project Report 85/105, Dept. of Primary Industries and Energy, Canberra, 213 pp.

Northcote, K. H., 1979. A factual key for the recognition of Australian soils. Relin Technical Publications, Coffs Harbour, New South Wales, 123 pp.

Northcote, K. H et al, 1960-1968. Atlas of Australian Soils, sheets 1-10 with explanatory data. CSIRO Australia and Melbourne University Press.

Peel, M.C., Chiew, F.H.S., Western, A.W. and McMahon, T.A., 2001.Extension of Unimpaired Monthly Streamflow Data and Regionalisation of Parameter Values to Estimate Streamflow in Ungauged Catchments, Report prepared for the National Land and Water Resources Audit, In http://audit.ea.gov.au/anra/water/docs/national/streamflow/streamflow.pdf

Ponce, V. M. and Hawkins, R. H., 1996. Runoff curve number: has it reached maturity. ASCE Jour. Hydrologic Engg., 1(1), 11-19.

Post, D.A. and Jakeman, A.J. 1999. Predicting the daily streamflow of ungauged catchments in S.E. Australia by regionalizing the parameters of a lumped conceptual rainfall-runoff model, Ecological Modelling, 123: 91-104.

Post, D.A., Jones, J.A. and Grant, G.E. 1998. An improved methodology for predicting the daily hydrologic response of ungauged catchments. Environmental Modelling and Software, 13: 395-403.

Rallison, R. E., 1980. Origin and evolution of the SCS runoff equation. In: Symposium of Watershed Management 1980, vol. II, ASCE, New York, 912-924.

Sivapalan, M., 2003. Prediction in ungauged basins: a grand challenge for theoretical hydrology. Hydrol. Process. 17, 3163-3170.

Snowy Mountains Engineering Corporation, 1971. Hydrology of small rural catchments. Aust. Water Resources Council Research Project 68/1, SMEC, Cooma, New South Wales. 